\title{
Tomographic Image of the Mid-Atlantic Plate Boundary in Southwestern Iceland
}

\author{
Ingi Th. BJARnason ${ }^{1}$ And William Menke \\ Lamont-Doherty Earth Observatory of Columbia University, Palisades, New York \\ Department of Geological Sciences, Columbia University, New York \\ Ólafur G. Flóvenz \\ Orkustofnun, Reykjavik, Iceland \\ David Caress \\ Lamont-Doherty Earth Observatory of Columbia University, Palisades, New York
}

The $170 \mathrm{~km}$ South Iceland Seismic Tomography (SIST) profile extends from the west and across the Mid-Atlantic Ridge spreading center in the Western Volcanic Zone and continues obliquely through the transform zone (the South Iceland Seismic Zone) to the western edge of the Eastern Volcanic Zone. A total of 11 shot points and 210 receiver points were used, allowing precise travel times to be determined for 1050 crustal $P$ wave rays and 180 wide-angle reflections. The large amplitudes of the wide-angle reflections and an apparent refractor velocity of $7.7 \mathrm{~km} / \mathrm{s}$ are interpreted to be from a relatively sharp Moho at a depth of $20-24 \mathrm{~km}$. This interpretation differs from the earlier models (based on data gathered in the 1960s and 1970s), of a $10-15 \mathrm{~km}$ thick crust underlain by a upper mantle with very slow velocity of 7.0-7.4 km/s. Nevertheless, these older data do not contradict our new interpretation. Implication of the new interpretation is that the lower crust and the crust-mantle boundary are colder than previously assumed. A two-dimensional tomographic inversion of the compressional travel times reveals the following structures in the crust: (1) a sharp increase in thickness of the upper crust ("layer 2A") from northwest to southeast and (2) broad updoming of high velocity in the lower crust in the Western Volcanic Zone, (3) depth to the lower crust ("layer 3 ") increases gradually from $3 \mathrm{~km}$ at the northwestern end of the profile to $7 \mathrm{~km}$ at the southeastern end of the profile, (4) a low-velocity perturbation extends throughout the upper crust and midcrust into the lower crust in the area of the transform in south Iceland (South Iceland Seismic Zone), and (5) an upper crustal high-velocity anomaly is associated with extinct central volcanos northwest of the Western Volcanic Zone. The travel time data do not support the existence of a large ( $>0.5 \mathrm{~km}$ thick) crustal magma chamber in this part of the Western Volcanic Zone but do not exclude the possibility of a smaller one.

\section{INTRODUCTION}

\section{Geology of Transect}

Iceland was built by volcanic rocks generated at a midocean ridge, beginning about $16 \mathrm{Ma}$. The volcanic pile observed at the surface is conventionally divided into four stratigraphic age groups: (1) postglacial, last 9000-13,000 years; (2) upper Pleistocene, back to 0.7 Ma; (3) Plio-Pleistocene, 0.7-3.1 Ma; (4) Tertiary, older than 3.1 Ma [Samundsson, 1979]. The source of the volcanism is a the rift system in Iceland. In southwest and south Iceland the rift system consists of the overlapping spreading centers in the Western and Eastern Volcanic Zones (WVZ, EVZ; Plate 1 and Figure 1). The continuation of the spreading center in central and northeast Iceland is called the Northern Volcanic Zone (NVZ). The spreading center in southwest Iceland made a ridge jump at $7 \mathrm{Ma}$ from the Snæfellsnes peninsula to its current position in the WVZ [Pálmason and Samundsson, 1974; Semundsson, 1979]. The Borgarfjördur unconformity (BUC, at $820 \mathrm{~km}$ on the profile, Figure 1) marks

\footnotetext{
${ }^{1}$ Now at Carnegie Institution of Washington, Washington, D.C.

Copyright 1993 by the American Geophysical Union.
}

the boundary between the volcanic pile originating from the previous position of the spreading center and the volcanic pile originating from the present position of the spreading center in the WVZ. The EVZ is a propagating rift that started its southern transgression from central Iceland at $3 \mathrm{Ma}$ [Sæemundsson, 1979]. The formation of the EVZ has been interpreted as a ridge jump in progress from the WVZ to the EVZ [Pálmason and Semundsson, 1974; Semundsson, 1979; Einarsson and Eiriksson, 1982; Oskarsson et al., 1985]. The EVZ is a young geological feature in south Iceland, and most of its volcanic products are confined within the zone. Therefore most of the volcanic pile between the WVZ and EVZ originates from the WVZ or off-axis volcanism between these two overlapping spreading centers.

The South Iceland Seismic Zone (SISZ) is a fracture zone at a nascent stage of development that accommodates leftlateral transform motion between the the EVZ and rifting on the Reykjanes Ridge (Plate 1 and Figure 1). However, no east-west surface fractures are observed within the zone. The left-lateral motion of the SISZ is accommodated by "bookshelf" type faulting (i.e., many parallel, north-south striking strike-slip faults) [Einarsson and Eiriksson, 1982; Hackman et al., 1990; Bjarnason et al., 1993]. The SIST profile traverses the SISZ obliquely between $720-735 \mathrm{~km}$ (Figure 1).

Seismic Structure of Iceland, Previous Work

The earliest publications on results from seismic refrac- 


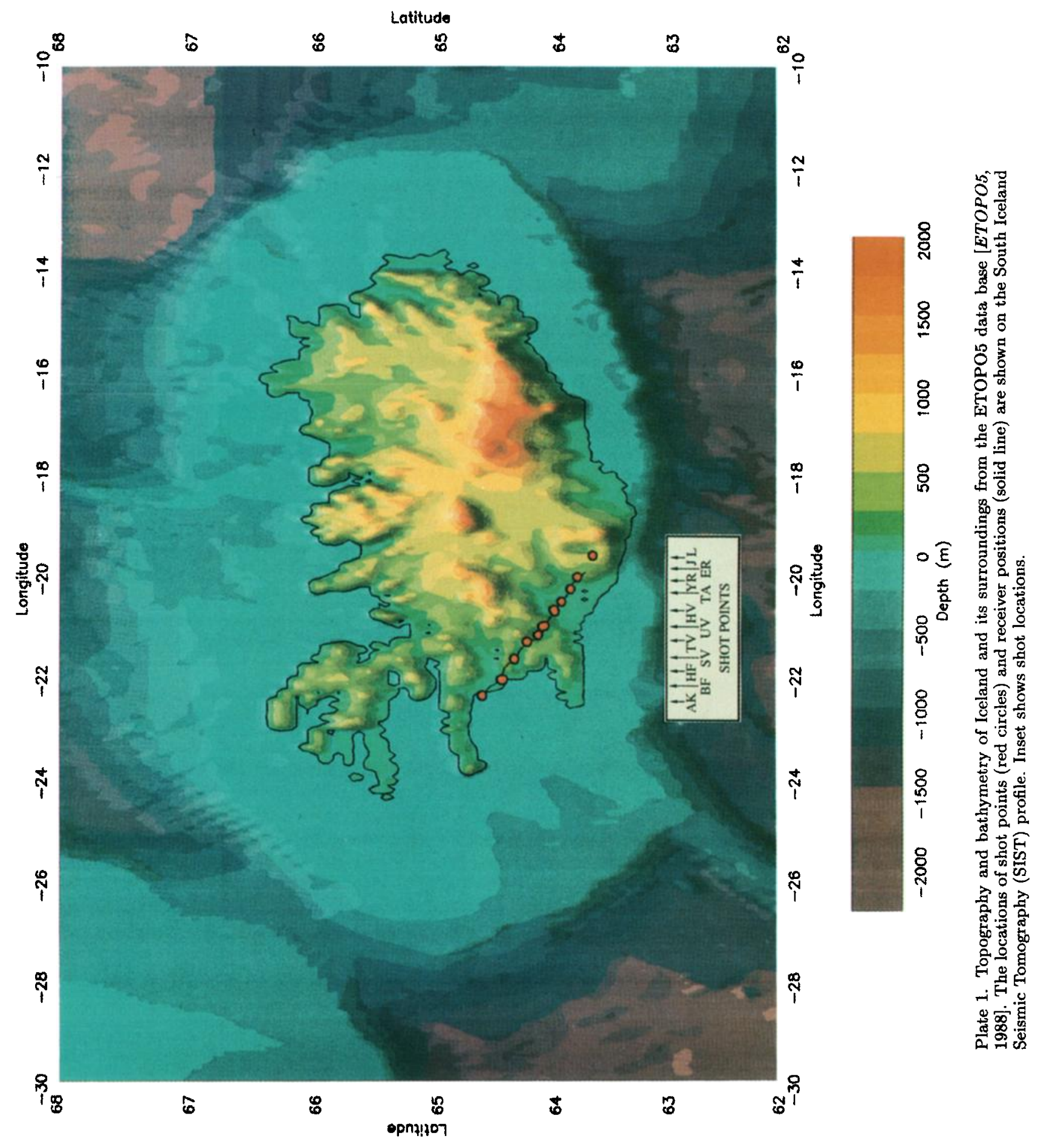




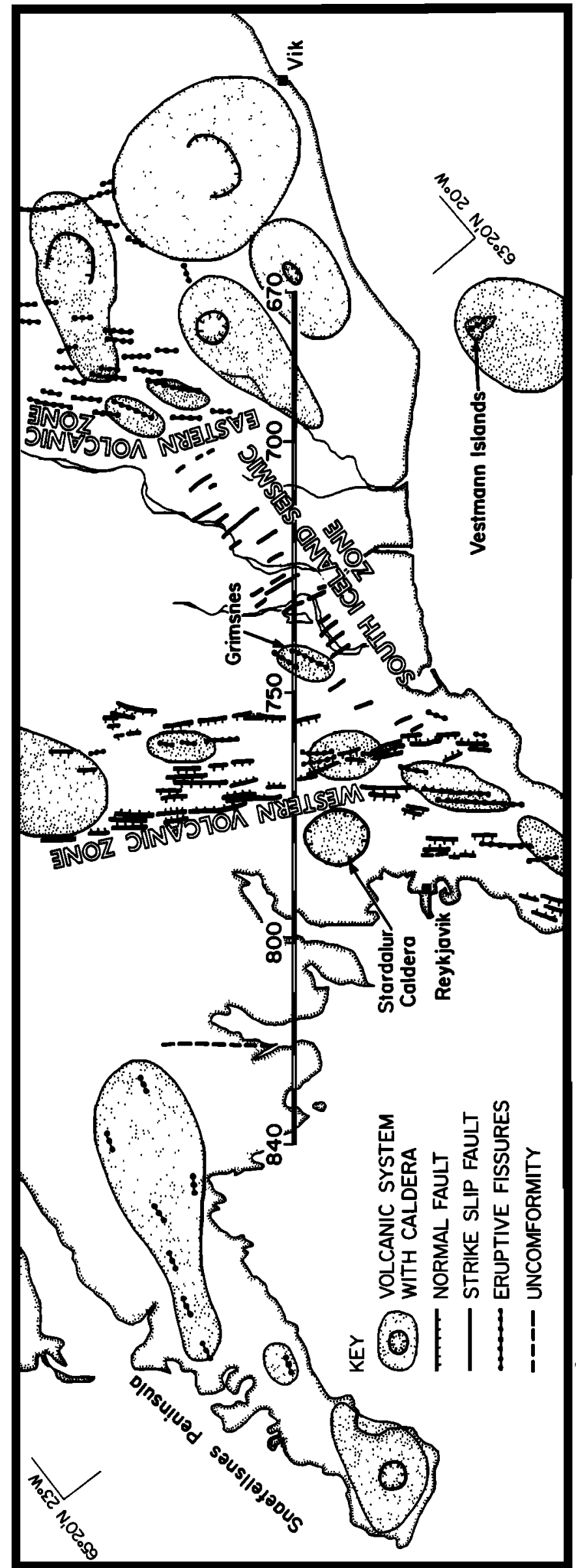

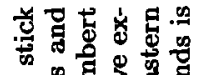

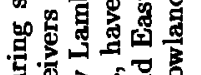

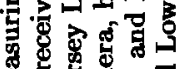

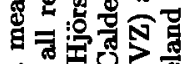

\%

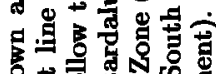

通范

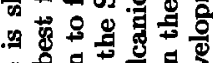

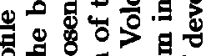

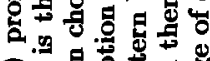

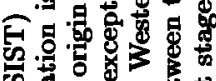

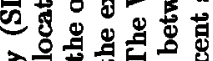

索少

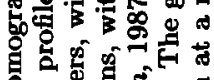

今 \&

苜

के

需焉

\&. 영 है

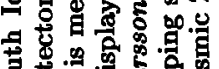

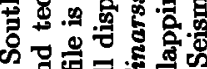

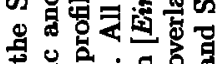

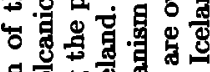

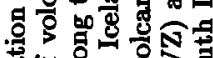

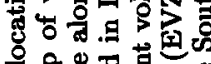

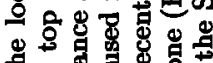

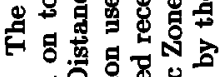

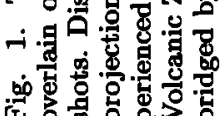


tion experiments in Iceland date back to the 1960s and early 1970s [Bath, 1960; Tryggvason and Bath, 1961; Pálmason, 1971; Pálmason and Semundsson, 1974; Zverev et al., 1975]. Pálmason [1971] synthesized the results of over 80 low-resolution (1-4 km station spacing) refraction profiles and compiled an average velocity model for Iceland. The model consists of four crustal layers and an anomalously slow upper mantle with $P$ wave velocity of $7.2 \mathrm{~km} / \mathrm{s}$. The velocities of the crustal layers correspond closely to velocities of oceanic crust (layers 1, 2A, 2B, and 3) but are 2-3 times thicker in Iceland. Depth to the lower crust varies considerably between 3 and $10 \mathrm{~km}$, and the total crustal thickness is rather poorly constrained but likely is between 10 and $\mathbf{1 5}$ km [Pálmason, 1971; Flóvenz, 1980; Flóvenz and Gunnarsson, 1991]. Flóvenz [1980] showed that Icelandic refraction data could be better interpreted in terms of a continuous velocity-depth profile rather than a layered structure with sharp discontinuities. This interpretation is consistent with recent models for oceanic crust [e.g., Minshull et al., [1991].

Interpretations of anomalously slow upper mantle under Iceland (velocities between 7.0 and $7.4 \mathrm{~km} / \mathrm{s}$ ) were based on the following reasoning: (1) The highest velocities observed in these older seismic refraction experiments are between 7.0-7.4 km/s [Bath, 1960; Pálmason, 1971; Gebrande et al., [1980]; (2) teleseismic travel times measured in Iceland are about $1.6 \mathrm{~s}$ slower than travel times measured on the European continent and Greenland [Tryggvason, 1964; Long and Mitchell, 1970] and could be explained with upper mantle velocities of $7.4 \mathrm{~km} / \mathrm{s}$ extending to depths of $160-240 \mathrm{~km}$; (3) high temperatures beneath Iceland (due to the hotspot), $1000-1100^{\circ} \mathrm{C}$ at $10-20 \mathrm{~km}$ depth produce a large percentage of melt that leads to low mantle velocities (in the 7.0-7.4 $\mathrm{km} / \mathrm{s}$ range) [Pálmason and Semundsson, 1974; Gebrande et al., 1980], (4) a high-conductivity layer is found under a large part of Iceland in approximately the depth range $10-20 \mathrm{~km}$, indicating partially molten upper mantle in that depth range [Beblo and Björnsson, 1980; Eysteinsson and Hermance, 1985].

The RRISP Working Group [1980] ran an 800-km-long refraction profile that traversed the flanks of the Reykjanes Ridge and continued on land over central Iceland, in order to better determine the seismic structure of the upper mantle under Iceland and the Mid-Atlantic Ridge (MAR). The RRISP study determined that 10-m.y.-old crust on the suboceanic Reykjanes Ridge is underlain by slow $(7.7 \mathrm{~km} / \mathrm{s})$ mantle at $10 \mathrm{~km}$ depth but found that velocity increases to a more "normal" upper mantle velocity of $8.2 \mathrm{~km} / \mathrm{s}$ at 16 $\mathrm{km}$ depth [Goldflam et al., 1980]. Fundamentally different upper mantle velocities were found beneath Iceland, ranging from $7.0 \mathrm{~km} / \mathrm{s}$ at the base of the crust at approximately 15 $\mathrm{km}$ depth to $7.4 \mathrm{~km} / \mathrm{s}$ at the maximum penetration depth of $30 \mathrm{~km}$ in this experiment [Gebrande et al., 1980]. The RRISP experiment did not support the findings of previous lower resolution Soviet studies of $40-60 \mathrm{~km}$ crustal thickness and upper mantle velocities under Iceland in the range 7.8-8.2 km/s [Zverev et al., 1975]. Accordingly, the RRISP experiment affirmed interpretations of anomalously slow upper mantle under Iceland and the relatively "normal" crustal and upper mantle oceanic velocity structure of the Reykjanes Ridge.

The seismic structure of the Kolbeinsey Ridge, the part of the MAR immediately north of Iceland, has not been studied in any detail [Flóvenz and Gunnarsson, 1991]. However, the structure of the Iceland-Faeroe Rise (IFR) (southeast of Iceland) is well determined. The IFR is thought to have been formed by interaction of the Iceland hotspot with the Mid-Atlantic spreading center at 40-55 Ma [Morgan, 1978; Vink, 1984]. The crustal structure of the IFR is similar to that of Iceland but is thicker, $28-35 \mathrm{~km}$ thick, and has subcrustal velocity of $7.8 \mathrm{~km} / \mathrm{s}$ [Zverev et al., 1975; Bott and Gunnarsson, 1980].

A low-resolution, three-dimensional tomographic image of Iceland, based on teleseismic $P$ wave travel times [Tryggvason et al., 1983] demonstrates significant lateral heterogeneity in the crust and upper mantle of Iceland. Compressional velocities in the upper $75 \mathrm{~km}$ (the "pixel" height in their inversion) increase with lateral distance from the spreading center by about $4 \%$. (Their type of inversion is not able to determine the average velocity, only lateral gradients.)

\section{Experimental Design, Data Acquisition AND ANalysis}

The SIST profile images a vertical slice through Earth that strikes northwest-southeast across southern Iceland (Plate 1). It crosses the major geological features associated with MAR rifting, such as the BUC, WVZ, and SISZ. The source-receiver distribution is fine enough to permit highresolution tomography in the upper crust, where targets such as magma chambers, fault zones, and shallow volcanic intrusions may occur. The profile is long enough that seismic rays from the longest offsets penetrate into the mantle, permitting conventional, low resolution refraction measurements of the lower crust, Moho, and uppermost mantle.

\section{Data Acquisition}

The multiple offset refraction experiment was designed in the following way: Long range shots, necessary to determine the crustal structure, were placed at distances up to $170 \mathrm{~km}$. Higher shot-receiver density was put around the most interesting imaging targets, the WVZ, and the SISZ to improve resolution. The highest shot and receiver density was over and around the WVZ and in the South Iceland Lowlands (between 695 and $795 \mathrm{~km}$ on the profile), with $10-20 \mathrm{~km}$ shot spacing and 0.5-1.0 km station spacing. The resulting profile was $170 \mathrm{~km}$ long, with the WVZ and SISZ approximately in its central part, with total of 11 shot points and 210 receiver points distributed along the profile (Table 1). Significant geological and geographical features along the profile are summarized in Table 2 . Although three-component data were recorded, only $\boldsymbol{P}$ wave arrivals are addressed here.

\section{Data}

Prominent coherent arrivals are visible to about $120 \mathrm{~km}$, and weak arrivals are visible to about $170 \mathrm{~km}$ on the profile (Figure 2). Large lateral velocity variations are observed along the profile. For example, there is up to $1 \mathrm{~s}$ travel time difference between stations with the same range $(20-40 \mathrm{~km})$ from each of the end shots, AK and JL (Figures 2 and 3). This travel time difference is an indication of a large difference in the upper-crustal structure at the end points of the profile. Consistent travel time delays are observed at stations in the SISZ, for both distant and close shots (e.g., in 105-120 km range from the AK shot, and in 60-70 km range from the JL shot, Figures 2 and 3). Travel time ad- 
TABLE 1. Acquisition Parameters

\begin{tabular}{cl}
\hline Parameter & Description \\
\hline 1 & $170 \mathrm{~km}$ refraction profile, approximately linear crossing ridge and transform \\
2 & 11 shot points in water, using 10 to $220 \mathrm{~kg}$ dynamite shots \\
3 & 210 receiver points \\
4 & three-component Mark Product L22D geophones \\
5 & digital recording with RefTek 72A and Sintrex PRS-4 instruments \\
6 & digitization at 200 samples/s and 12 and 16 bits/sample \\
7 & timing to 0.01 s accuracy by Omega radio time \\
6 & shot and receiver points located by both GPS and aerial photos, \\
7 & with approximately 30-m accuracy \\
8 & 1050 three-component seismograms with good signal to noise ratios \\
\hline
\end{tabular}

TABLE 2. Significant Features

\begin{tabular}{|c|c|c|c|c|c|c|}
\hline Name & Feature & Profile, $\mathrm{km}$ & Latitude* $^{*}$ & Longitude* & Latitude $^{*}$ & Longitude* \\
\hline & profile & 840.0 & 64.6000 & -22.4259 & & \\
\hline AK (Akrar) & shot & 841.0 & 64.6052 & -22.4425 & & \\
\hline BF (Borgarfjördur) & shot & 818.3 & 64.4812 & -22.0673 & & \\
\hline HF (Hvalfjördur) & shot & 794.9 & 64.3524 & -21.6841 & & \\
\hline SV (Stíflisdalsvatn) & shot & 774.5 & 64.2393 & -21.3530 & & \\
\hline TV (Thingvallavatn) & shot & 762.6 & 64.1730 & -21.1610 & & \\
\hline UV (Úlfljótsvatn) & shot & 753.9 & 64.1243 & -21.0213 & & \\
\hline HV (Hestvatn) & shot & 734.4 & 64.0148 & -20.7099 & & \\
\hline TA (Thjórsá) & shot & 723.6 & 63.9538 & -20.5385 & & \\
\hline YR (Ytri Rangá) & shot & 708.4 & 63.8677 & -20.2985 & & \\
\hline ER (Eystri Rangá & shot & 695.2 & 63.7926 & -20.0913 & & \\
\hline \multirow[t]{2}{*}{ JL (Jökullón) } & shot & 669.5 & 63.6455 & -19.6911 & & \\
\hline & profile & 670.0 & 63.6483 & -19.6989 & & \\
\hline Borgarfjördur & fjord & 813.8-819.0 & 64.4562 & -21.9925 & 64.4851 & -22.0788 \\
\hline Hvalfjördur & fjord & 794.5-798.0 & 64.3502 & -21.6776 & 64.3695 & -21.7346 \\
\hline Stardalur & extinct volcano & 778.0 & 64.2587 & -21.4095 & & \\
\hline WVZ & spreading center & 753.8-767.0 & 64.1246 & -21.0189 & 64.1975 & -21.2319 \\
\hline Grímsnes & volcanic center & $740.0-745.6$ & 64.0778 & -20.7991 & 64.1235 & -20.8884 \\
\hline SISZ & transform & 721.3-734.0 & 63.9405 & -20.5013 & 64.0125 & -20.7035 \\
\hline
\end{tabular}

* All latitudes and longitudes are for the point of projection of features onto the profile.

vances (high velocity perturbations) are associated with two extinct central volcanos northwest of the WVZ (Skardsheidi and Stardalur caldera in distance ranges $31-39 \mathrm{~km}$ and $62-71$ $\mathrm{km}$ from the AK shot, Figures 2 and 3). A number of later phases are observed in the data. The most prominent later arrival has the characteristics of a wide-angle reflection. It is observed in four record sections of the shots with the largest offsets. The onset of this phase is at a reduced travel time of $1.5 \mathrm{~s}$ and at an offset of approximately $80 \mathrm{~km}$ (Figure 2).

Travel times were picked by hand and are believed to be accurate to about $0.015 \mathrm{~s}$ for first arrivals and $0.050 \mathrm{~s}$ for later arrivals.

\section{Data Analysis}

The similarity of Icelandic crust to oceanic crust is easily seen in the exemplary travel time curves (Figure 3). Layer $2 \mathrm{~A}(3.5 \pm 0.5 \mathrm{~km} / \mathrm{s})$ is at the surface of the HV shot, followed by layer $2 \mathrm{~B}(5.2 \pm 0.4 \mathrm{~km} / \mathrm{s})$ and layer $3(6.5 \pm 0.3$ $\mathrm{km} / \mathrm{s}$ ). Layer $2 B$ is just below the surface at the $A K$ shot. Velocities of $7.2 \pm 0.2 \mathrm{~km} / \mathrm{s}$ have been attributed to a slow upper mantle in Iceland. However, in this study a higher maximum apparent velocity of $7.7 \mathrm{~km} / \mathrm{s}$ is observed from the JL shot.

Further data analysis was done in two stages. First, the two-dimensional crustal seismic velocity structure along the SIST profile was imaged by tomographic inversion of crustal travel times. Second, the nature of the observed deep reflector was explored by two-dimensional forward modeling of the reflected arrivals using the tomography results.

\section{Tomographic Inversion}

In this study we use the tomographic inversion formulation of Caress et al. [1992]. The velocity structure is parameterized as a staggered two-dimensional grid divided into triangles. The velocity within each triangle is determined by linear interpolation of the vertex nodal values, giving a continuous velocity model with constant velocity gradients in each triangle. Rays can be traced three dimensionally through the two-dimensional model, allowing the actual geometry of the seismic experiment to be accurately incorporated into the inverse problem. Geometrical ray paths and travel time residuals are calculated by ray tracing through a starting velocity model; the residuals are then inverted for the perturbation to the starting model which is required to satisfy the travel time data. The inversion is regularized by the addition of a smoothing operator which penalizes roughness as measured by the second derivatives of the velocity perturbation.

The initial data analysis consisted of one-dimensional forward modeling of individual record sections associated with the shot points. The resulting 11 one-dimensional velocity models were linearly interpolated into the two-dimensional starting velocity model used for the tomographic inversion (Plate 2). We used 1020 travel time picks in the inversion; the associated ray paths through the starting velocity model are shown in Plate 2. We inverted the travel time data using a number of different grid spacings and with differing amounts of smoothing applied. We found that somewhat 

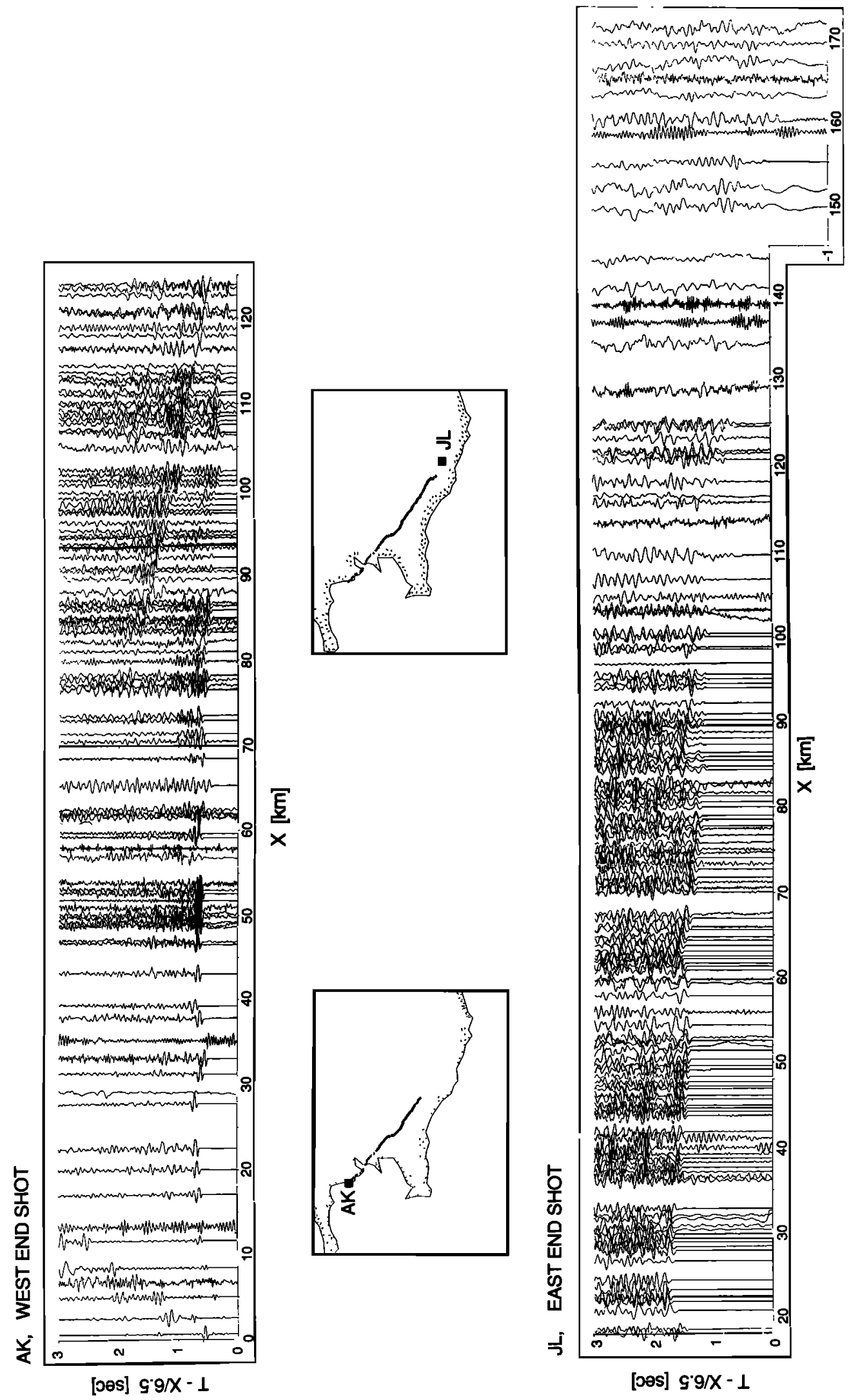

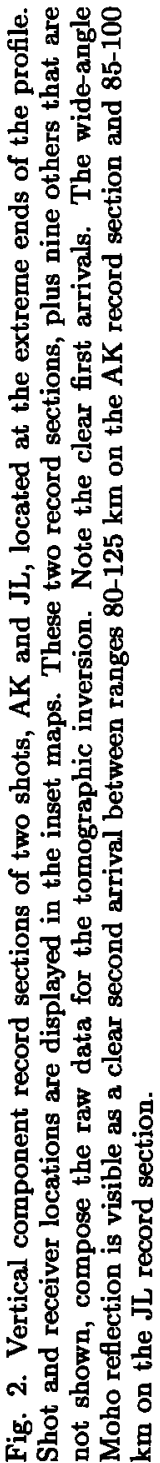

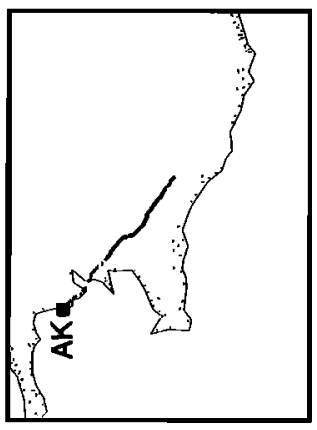

[oos] $99 / x-1$ 

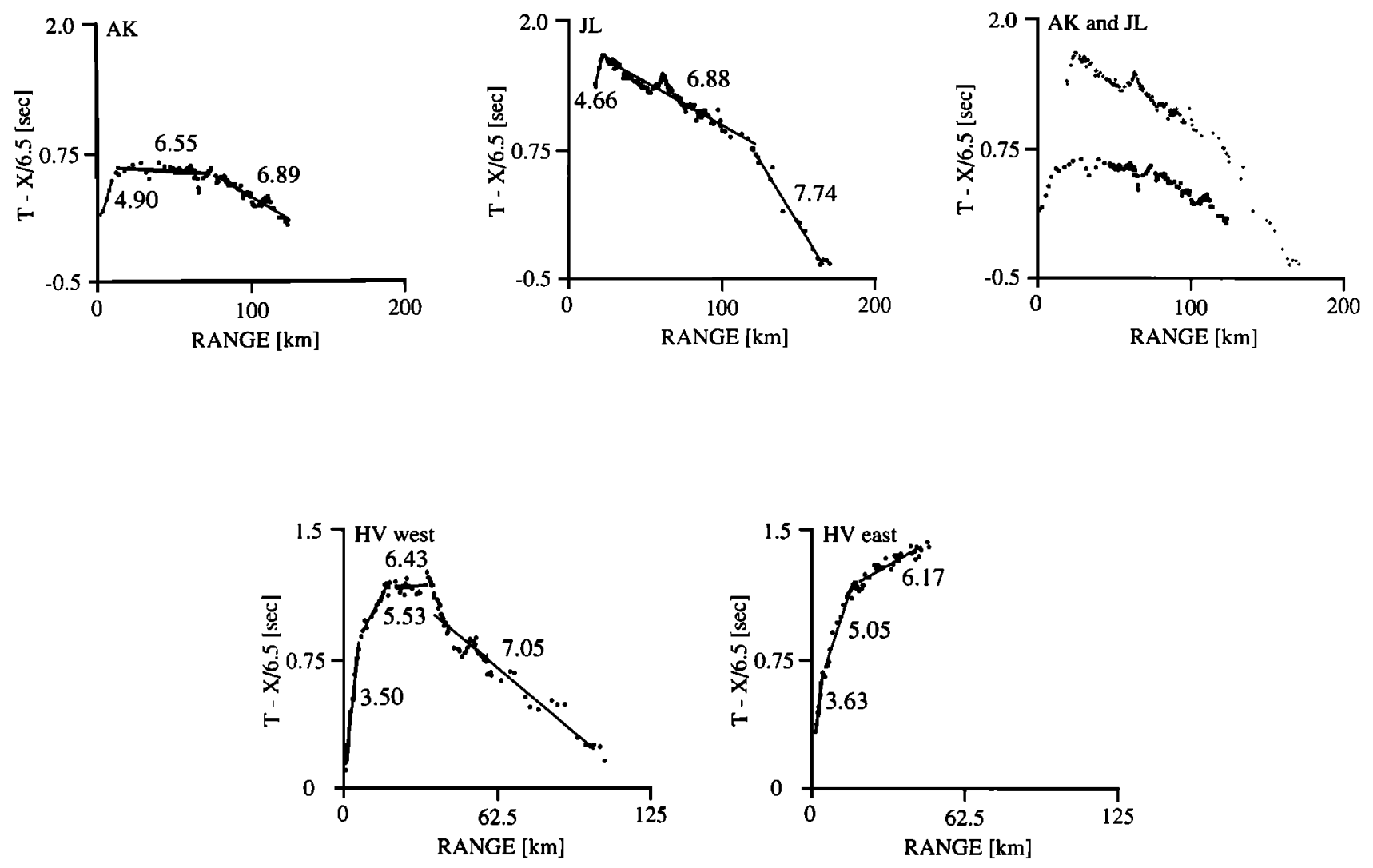

Fig. 3. $P$ wave reduced travel time curves for the shots AK and JL (which are at the west and east ends of the profile, respectively), and shot HV (which is close to the center) (Plate 1). Note that the $P$ wave has apparent velocities (in $\mathrm{km} / \mathrm{s}$ ) that are close to the characteristic velocities of the oceanic layers $2 \mathrm{~A}, 2 \mathrm{~B}, 2 \mathrm{C}$, and 3 . The $7.74 \mathrm{~km} / \mathrm{s}$ apparent velocity observed at large ranges for $\mathrm{JL}$ shot is slower than typical measurements of the upper mantle but is much higher than previously accepted values $(7.0-7.4 \mathrm{~km} / \mathrm{s})$. Note the large difference in travel time (up to $1 \mathrm{~s}$ ) between shots $\mathrm{AK}$ and JL at short offsets, which is related to large differences in upper crustal thickness between the east and west ends of the profile. Note the broad travel time delays centered at ranges 65 $\mathrm{km}$ and $110 \mathrm{~km}$ from shots $\mathrm{JL}$ and $\mathrm{AK}$, which is due to a low-velocity zone in the SISZ area.

better resolution was achieved with a coarser grid and less smoothing than with a finer grid and more smoothing. The highest resolution is obtained in the area of the WVZ down to approximately $5 \mathrm{~km}$ depth. In this area, station spacing is $0.5 \mathrm{~km}$ and shot spacing is $10 \mathrm{~km}$ (Plate 2). Away from the WVZ the station spacing varies between 0.5 and $1.5 \mathrm{~km}$, and the shot spacing is approximately $20 \mathrm{~km}$. Our preferred model was obtained using a $1-\mathrm{km}$ vertical and $10-\mathrm{km}$ lateral grid spacing; this velocity mesh extends to a depth of 15 $\mathrm{km}$, has a lateral extent of $190 \mathrm{~km}$, and includes 328 velocity nodes and 585 triangles. Plate 3 presents the results of the tomographic inversion, of the travel time data, which are discussed in detail in the next section of the paper.

The resolving power of the tomographic inversion is assessed with an impulse response method. Synthetic travel times are computed for the actual source-receiver configuration, but with a velocity structure that is homogeneous, except for a perturbation at a single node. These data are inverted to yield an estimated velocity model, which owing to imperfect resolution have perturbations at more than one node. In our case, we find the resolution to be very good (10 km horizontally, $1 \mathrm{~km}$ vertically) down to $8 \mathrm{~km}$ depth (Figure 4).

The fit of the final velocity model to the travel time picks indicate there are no systematic errors in the model and that the overall fit is excellent (Figure 5). The root-mean-square (rms) misfit of the travel time data relative to the final ve- locity model is $0.033 \mathrm{~s}$, a $97 \%$ variance reduction compared to the 0.19-8 rms misfit relative to the starting model. The rms misfit of the final model is close to the estimated 0.015$s$ average picking error, indicating that further iterations of the inversion are unnecessary.

\section{Wide-Angle Reflection Modelling}

In our data, clear wide-angle reflections are observed in the record sections of the four shots with the largest offsets. Assuming these are from the same reflector, we determined its depth by forward modeling of travel times using the Seis81 ray-tracing program [Cerveny and Psencik, 1981]. The upper $15 \mathrm{~km}$ of the velocity structure were determined by the results of the tomographic inversion. The lower part of the model was adjusted by trial-and-error forward modeling. Our data set only poorly constrains the velocity structure between $15 \mathrm{~km}$ depth and the depth to the top of the reflector, because few rays turn at those depths. In this depth range we have used a velocity of $7.1 \mathrm{~km} / \mathrm{s}$ at $15 \mathrm{~km}$ depth increasing linearly to $7.2-7.25 \mathrm{~km} / \mathrm{s}$ immediately above the reflector. The travel times of the wide-angle reflections can be modeled with a reflector at $20-22 \mathrm{~km}$ depth under the South Iceland Lowlands, deepening to $24 \mathrm{~km}$ northwest of the WVZ (Figure 6). The velocity is modeled as $7.5 \mathrm{~km} / \mathrm{s}$ just below the reflector and has a positive gradient, so that rays turning just beneath the reflector have an apparent velocity of about $7.6-7.7 \mathrm{~km} / \mathrm{s}$ and hence fit the travel times 

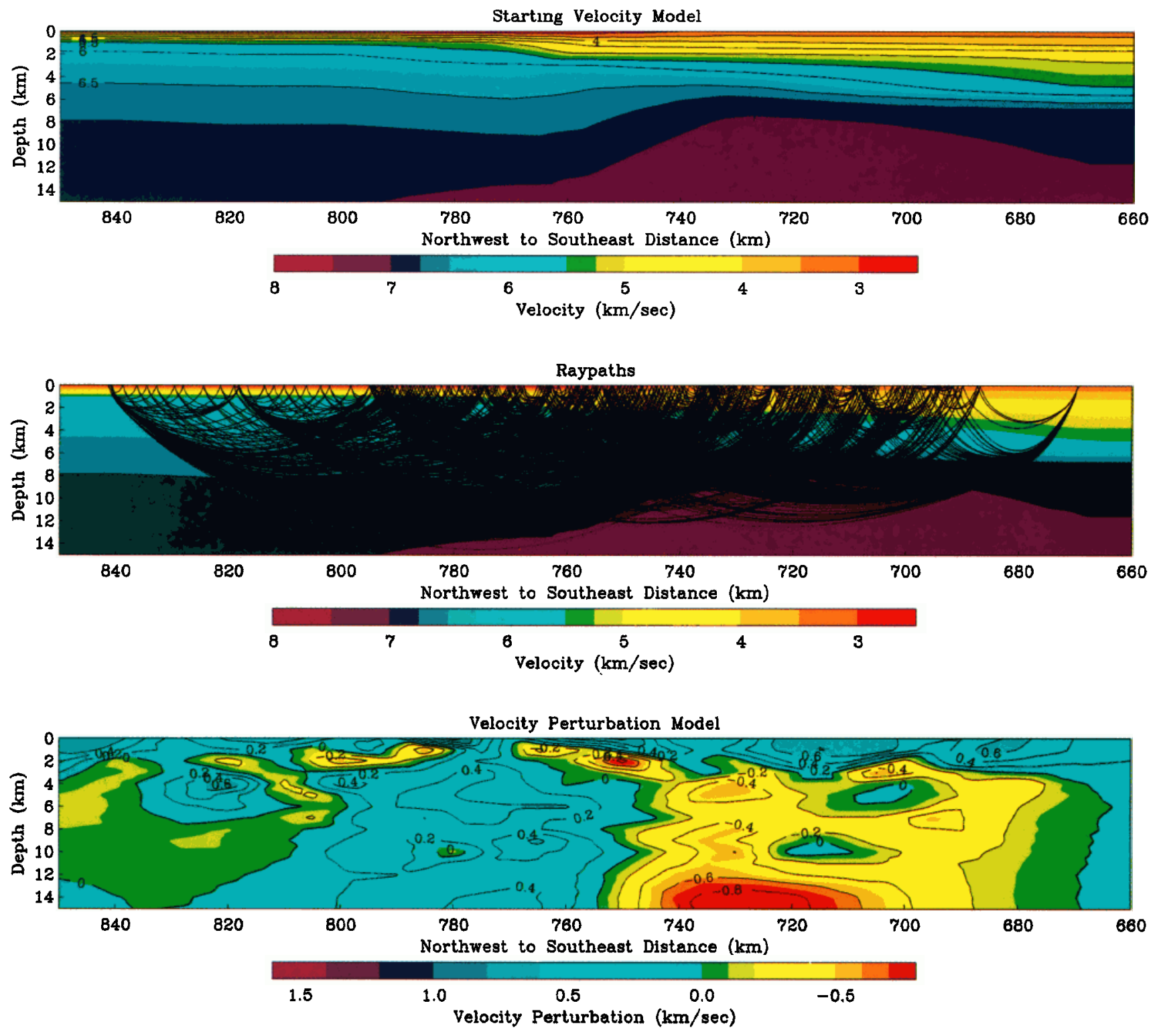

Plate 2. (Top) The two-dimensional starting model for the tomographic inversion based on interpolated onedimensional models along the profile. (Middle) The $1050 P$ wave ray paths through the starting model. (Bottom) Perturbations to the starting model as determined by the tomographic inversion of $P$ wave travel time residuals. Note that the perturbations are difficult to interpret visually, because the starting model is laterally heterogeneous.

of the observed mantle refractor in shot $\mathrm{JL}$ in Figure 6 . We interpret the reflector to be the Moho and discuss the reasoning for this interpretation below.

\section{Results AND Discussion}

\section{Crust}

On the basis of our data and previous knowledge of the velocity structure of the Icelandic crust we find it convenient to subdivide the crust in Iceland into three different units, upper crust, midcrust, and lower crust.

1. Upper crust (defined here as everything above the $\mathbf{5 . 0}$ $\mathrm{km} / \mathrm{s}$ contour, i.e., approximately layer $2 \mathrm{~A}$ ) has significant lateral variation and varies in thickness from 0.7 to $3.0 \mathrm{~km}$ (Plate 3). The upper crust has a very constant thickness between 0.7 and $1.2 \mathrm{~km}$ west of the WVZ. At the WVZ there is a sharp discontinuity in the thickness of the upper crust. Under the WVZ the thickness of the upper crust is approximately $2.0 \mathrm{~km}$, and east of the WVZ the thickness varies between 2.0 and $3.0 \mathrm{~km}$. No significant sedimentary layers occur along the profile.

Earlier refraction surveys [Pálmason, 1971; Flóvenz, 1980] show that the upper crust in Iceland varies in thickness from zero to $2.5 \mathrm{~km}$. The lowest values are found in areas of greatest glacial erosion and high alteration (secondary mineralization) connected with extinct central volcanos. The generally low values in the area west of the WVZ are due to erosion in glacial times. The maximum thickness of the upper crust is controlled by alteration processes. Almost all the material of the upper crust is made up of subaerial lava flows that subside due to the load of subsequent eruptive material. As the basalt is brought to greater depth it becomes increasingly altered due to secondary mineralization and the compressional wave velocity increases. When the temperature reaches approximately $250^{\circ} \mathrm{C}$, heavy minerals like epidote start to form, and the velocity exceeds $5.0 \mathrm{~km} / \mathrm{s}$ 

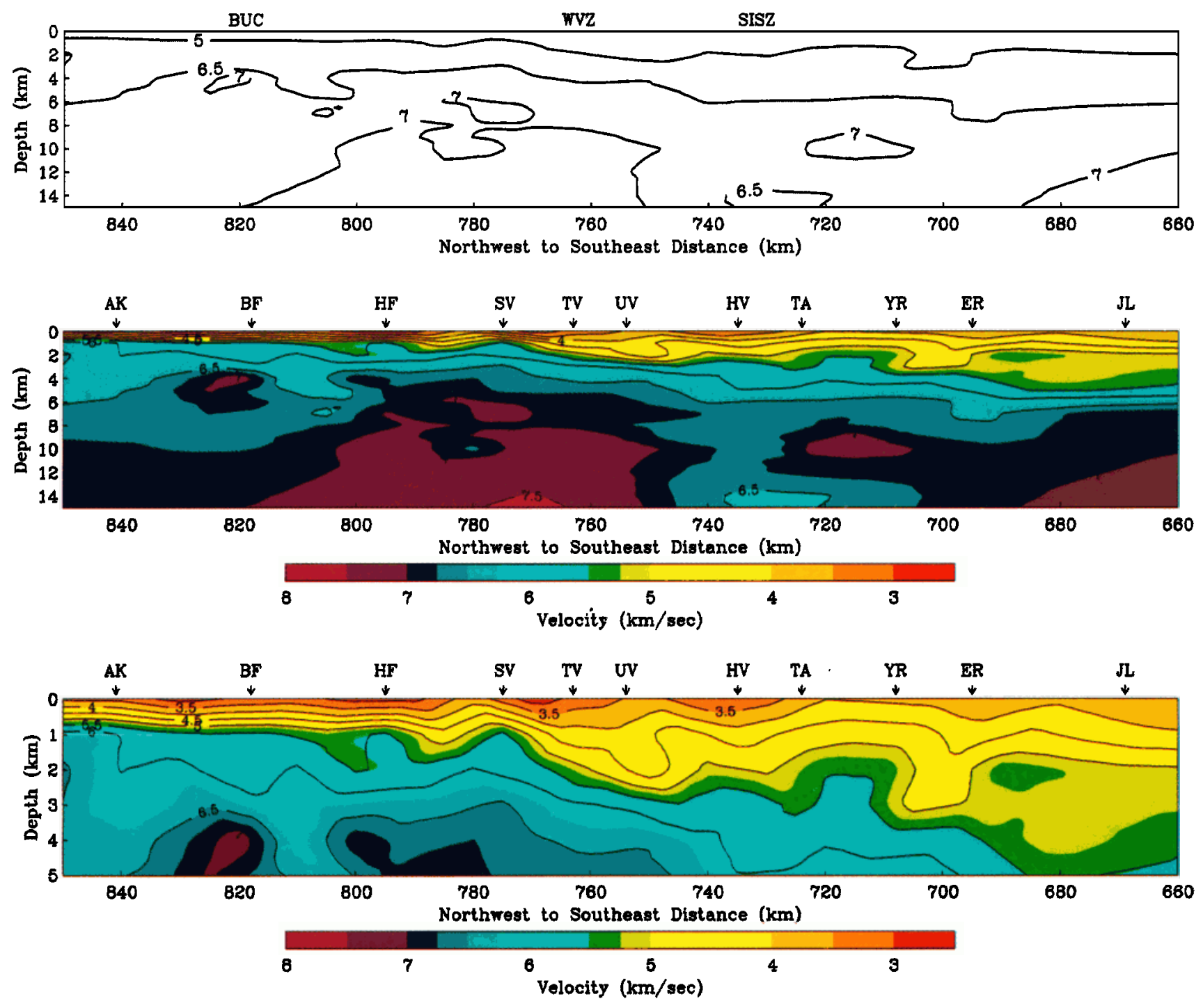

Plate 3. (Top) The major contours of the compressional wave velocity as determined by the tomographic inversion. The contours outline the shape of the upper crust (above $5.0 \mathrm{~km} / \mathrm{s}$ ), the midcrust (between $5.0-6.5 \mathrm{~km} / \mathrm{s}$ ) and the lower crust (below $6.5 \mathrm{~km} / \mathrm{s}$ ). The $7.0 \mathrm{~km} / \mathrm{s}$ contour outlines high-velocity zones within the lower crust. Major geological features on the profile associated with the MAR rifting are the BUC, WVZ, and SISZ. (Middle) Compressional wave velocity in the upper $15 \mathrm{~km}$ of the crust as determined by the tomographic inversion. Locations of the 11 shots along the profile are indicated (arrows). See text for discussion. (Bottom) Upper $5 \mathrm{~km}$ of the tomographic model.

which we define as the top of the midcrust. The temperature gradient within the volcanic zone and in its surroundings is always higher than $100^{\circ} \mathrm{C} / \mathrm{km}$ [Flóvenz and Sæmundsson, 1993] leading to a maximum thickness of $\sim 2.5 \mathrm{~km}$ for the upper crust. Thicker upper crust can only be formed in Iceland when lava is accumulated on older crust with a temperature gradient lower than $100^{\circ} \mathrm{C}$ (e.g., as a consequence of ridge jumps or propagation of rifts through older crust). The thick upper crust in the South Iceland Lowland is probably due to the ridge jumping from the WVZ to the EVZ.

2. The midcrust (defined here as everything between contours 5.0 and $6.5 \mathrm{~km} / \mathrm{s}$, i.e., layers $2 \mathrm{~B}$ and $2 \mathrm{C}$ ) has significant lateral variation in thickness from 2.0 to $4.5 \mathrm{~km}$ (Plate 3 ). The midcrust has relatively constant thickness of 2.0 $2.5 \mathrm{~km}$ under and to the west of the WVZ (except around $810 \mathrm{~km}$ on profile). There is rapid thickening of the midcrust east of the WVZ, where the thickness is between 3.0 and $4.5 \mathrm{~km}$. The thickening of the midcrust may be due to off-ridge volcanism. Several drill holes penetrate almost through the midcrust to just over $3 \mathbf{~ k m}$ and show that it is made of basaltic lava flows with increasing content of highertemperature alteration minerals like epidote.

3. The depth to the top of the lower crust (i.e. layer 2-3 boundary, defined by a sharp decrease in the velocity gradient at $\sim 6.5 \mathrm{~km} / \mathrm{s}$ ) is on average $4.5 \mathrm{~km}$, and it is 14 $20 \mathrm{~km}$ thick (Plate 3 .) The depth is relatively constant west of the WVZ, between 3.0 and $4.0 \mathrm{~km}$. Under the WVZ the depth is $4.3 \mathrm{~km}$, and it increases to $6.0-7.0 \mathrm{~km}$ east of the WVZ. Mutter and Mutter [1993] examining a large suite of published oceanic crustal profiles, find that the depth of the layer 2-3 boundary is remarkably constant $4.5 \mathrm{~km}$ below sea level, when depths are corrected to paleodepth at the time of seaffoor creation. The average depth of this boundary below south Iceland is also about $4.5 \mathrm{~km}$ below sea level. The nature of layer 3 in Iceland is still unknown since the deepest borehole in Iceland terminates a few hundred meters 

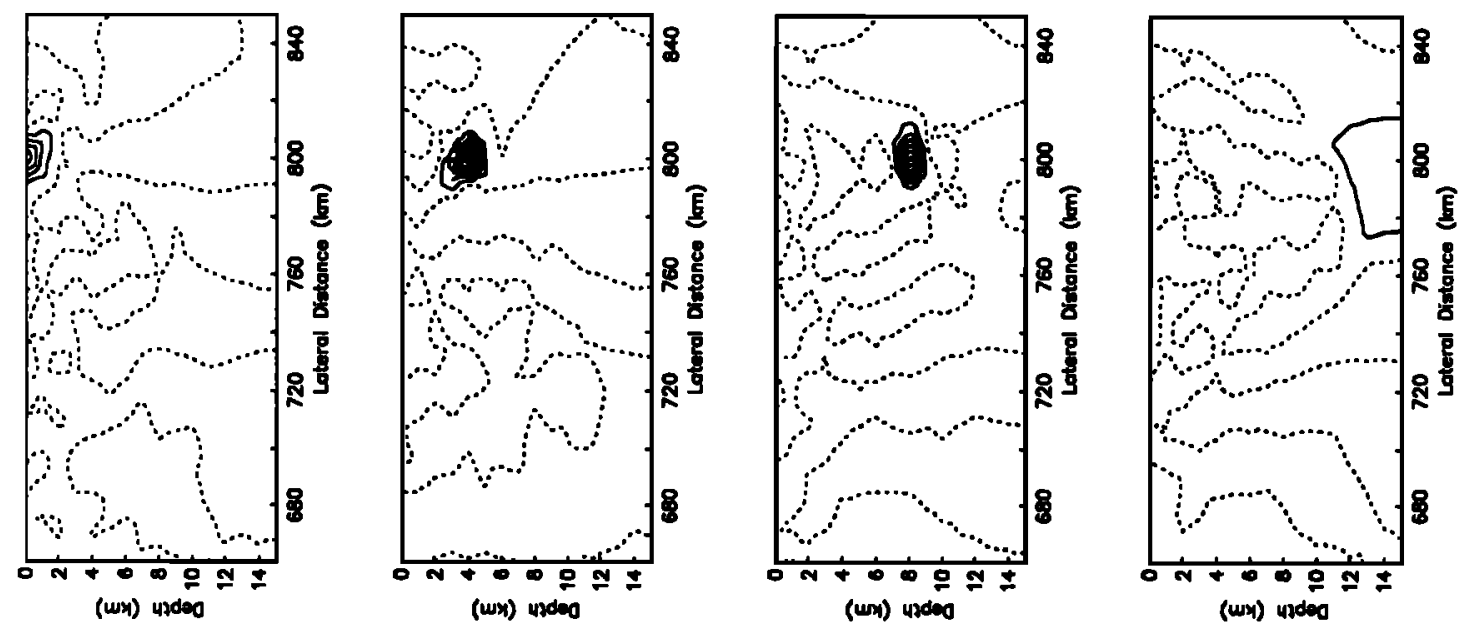

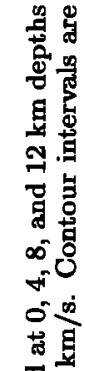
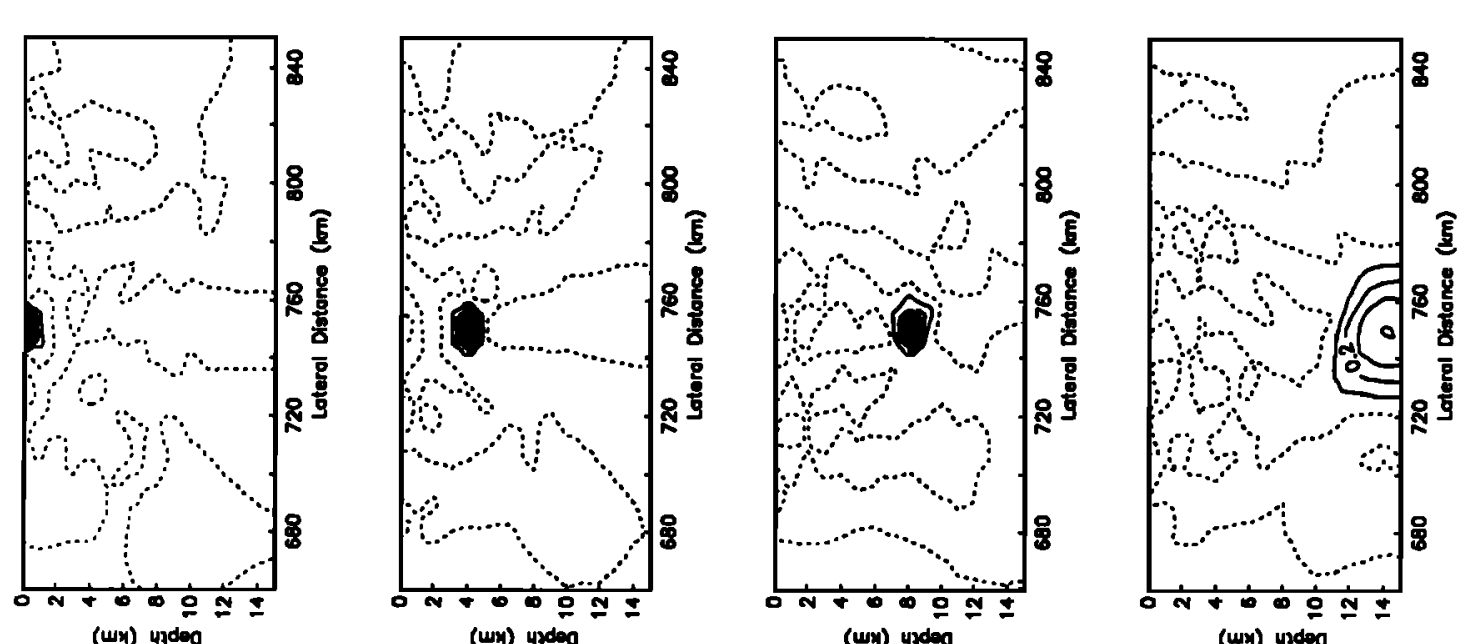

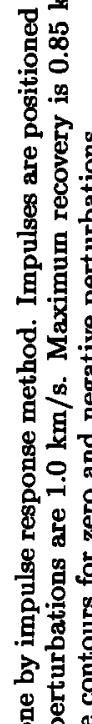
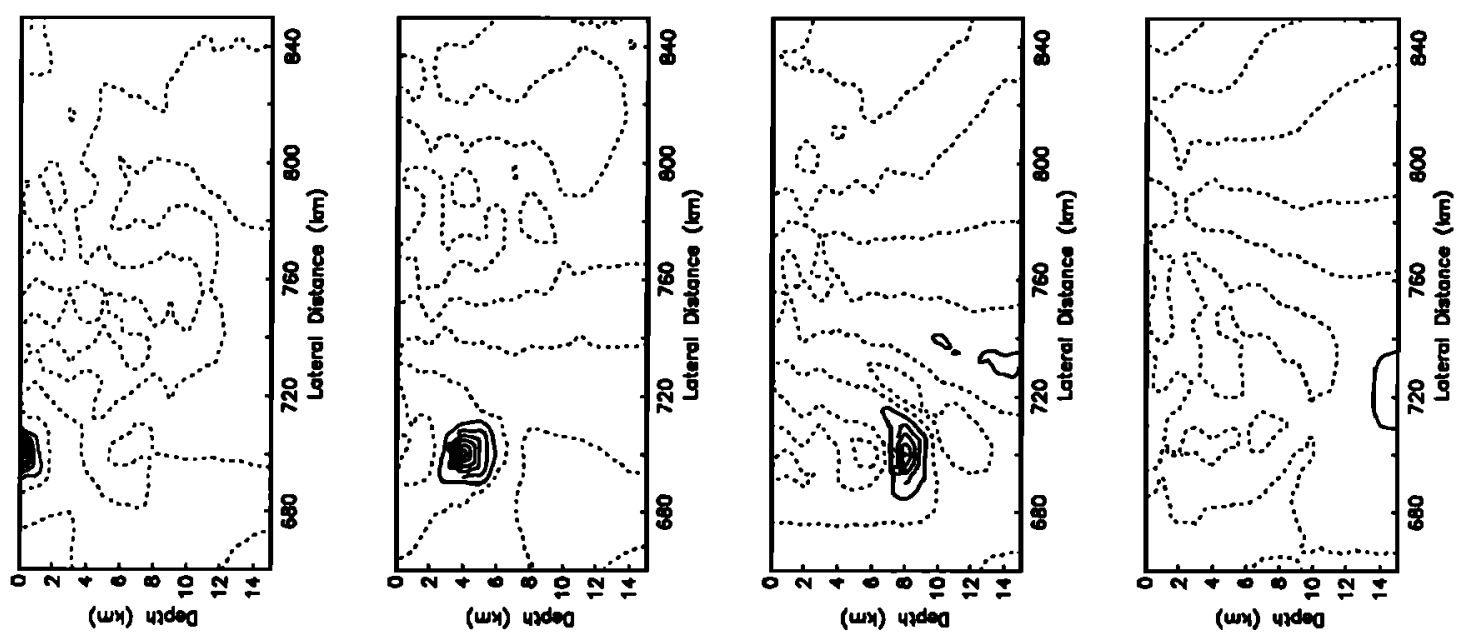

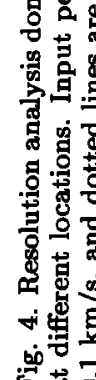

(wx) usdeo

(wy) $4 x d 00$

(ury) undeo 

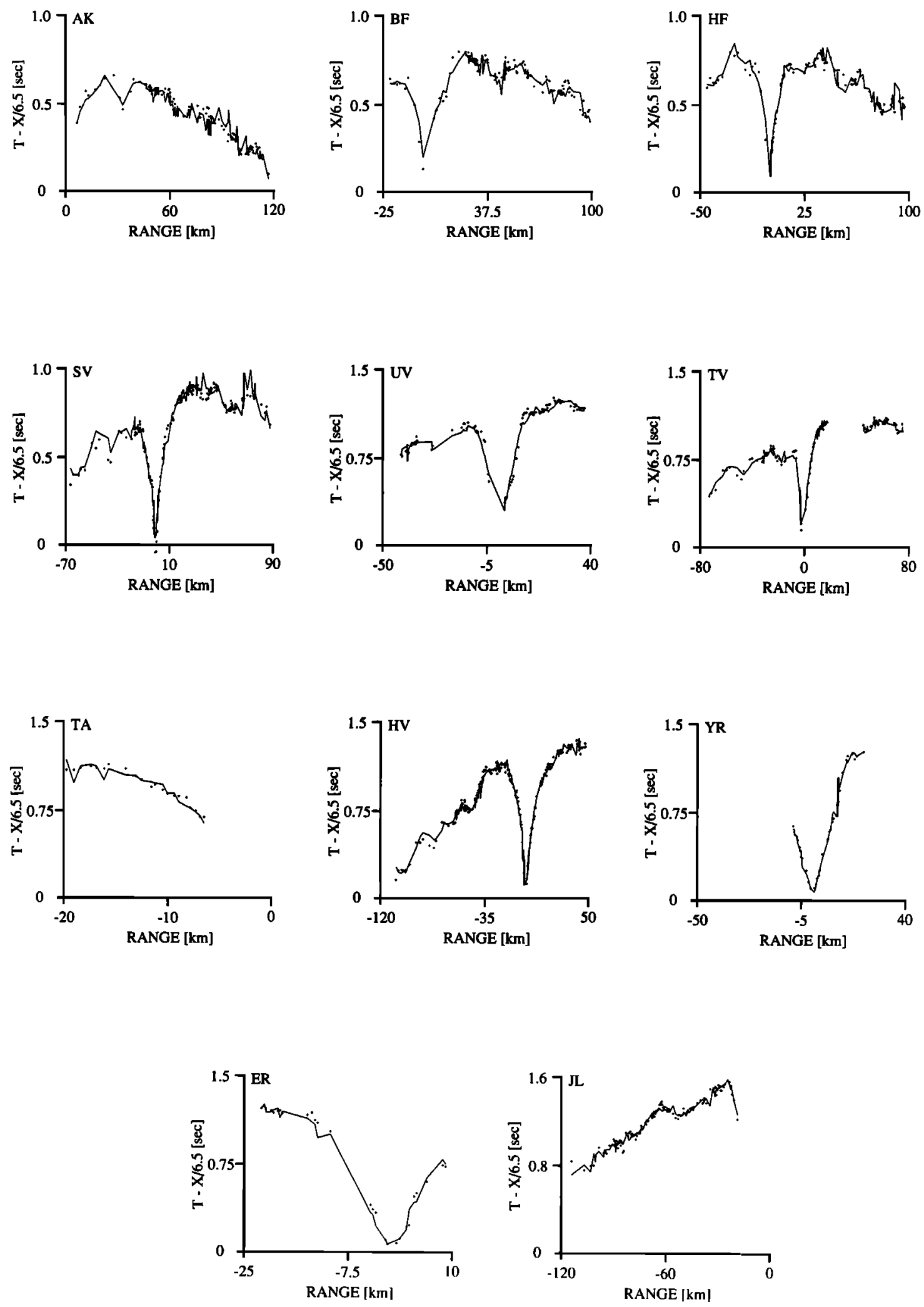

Fig. 5. $P$ wave travel time data (dots) and fits (solid curve) from the tomographic model. Notice that the misfit rarely exceeds $0.03 \mathrm{~s}$. 

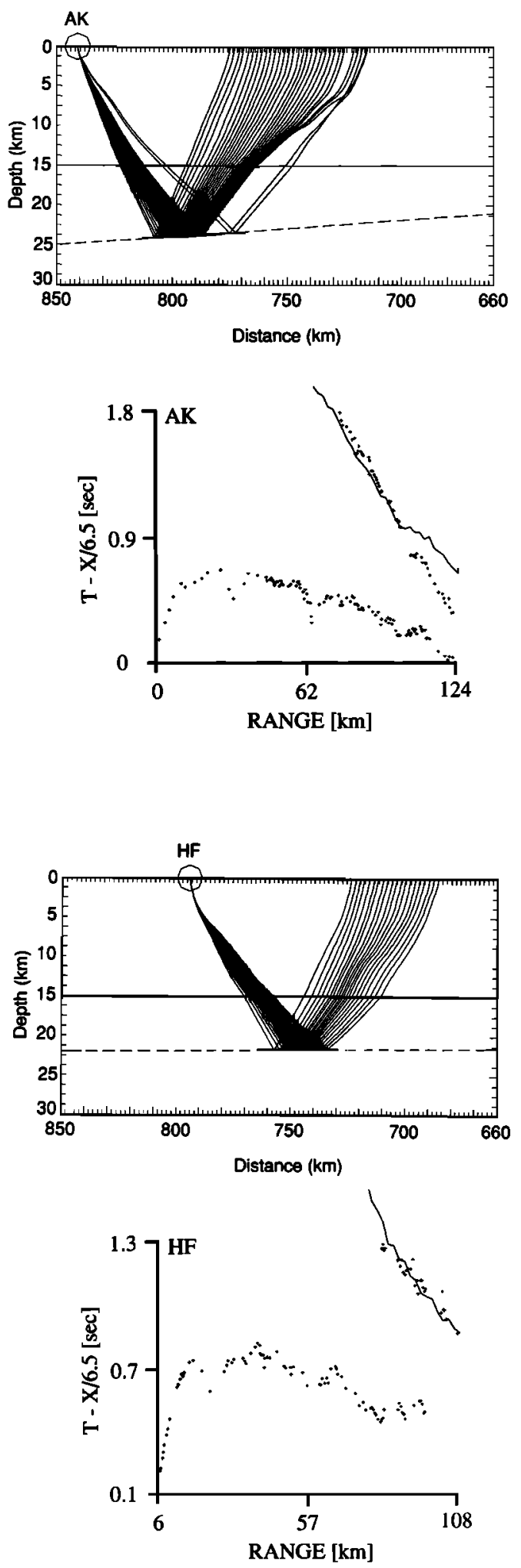
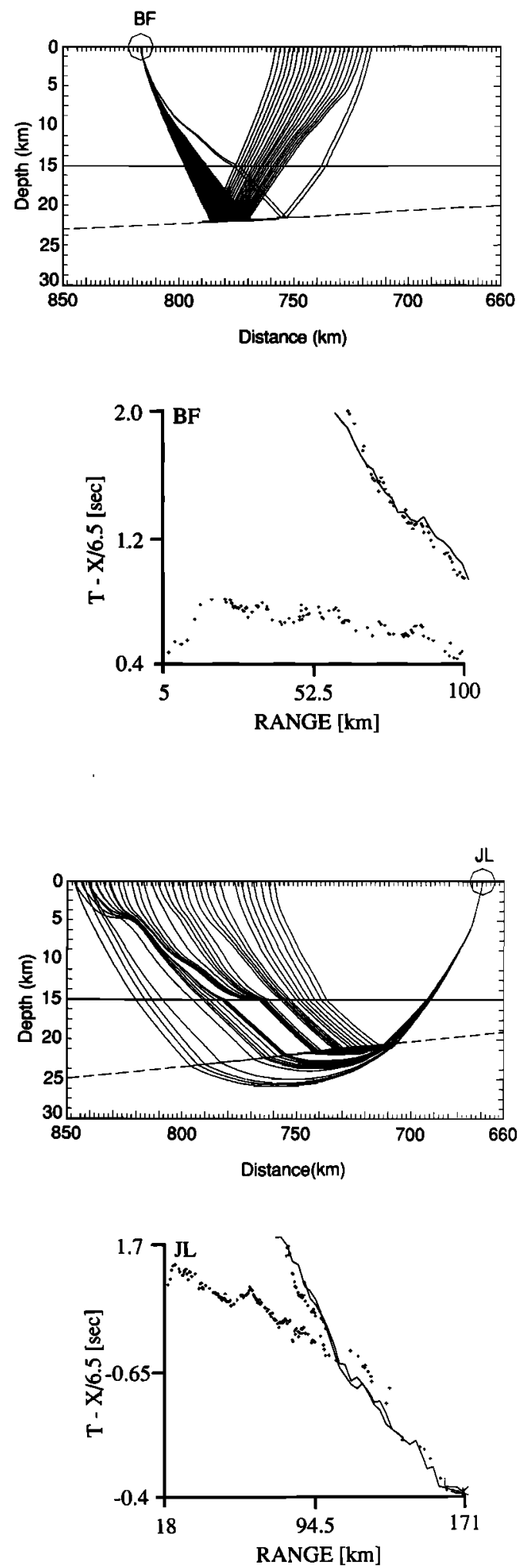

Fig. 6. Travel time (dots) of wide-angle reflections and fit (solid curve) from forward modeling of reflections with Seis81 program [Cerveny and Psencik, 1981]. The tomographic model was used in the upper $15 \mathrm{~km}$. The Moho is best modelled with slight deviations form a linear interphase (dashed line in the ray diagram), which dips gently to the west. 
above the boundary.

4. The crust in south Iceland is $20-24 \mathrm{~km}$ thick with a sharp reflector at the bottom which we interpret as the Moho. This is significantly thicker crust than has been postulated in previous investigations. A relatively sharp Moho is probably a common feature in Iceland, at least outside the volcanic zones.

This new model does not contradict the older data of Pálmason [1971] since we interpret his layer 4 (compressional velocity $7.2 \mathrm{~km} / \mathrm{s}$ ) as being the lowest part of the crust, underlain by a sharp Moho.

Layer 3 is disproportionately thicker than standard oceanic crust. The ratio of the thickness of layer 2 to layer 3 is about 3:5 (= 0.6) for typical oceanic crust from a slow spreading center such as the MAR [Minshull et al., 1991] but 4.5:17.5 $(=0.25)$ for south Iceland. The disproportionate thickness of layer 3 has been reported for thick oceanic crust elsewhere in the world [Mutter and Mutter, 1993].

Our lower crustal velocities are not well constrained but reach about 7.2-7.25 km/s just above the postcritical mantle reflector. A jump from 7.2 to $7.25 \mathrm{~km} / \mathrm{s}$ above the reflector to $7.5 \mathrm{~km} / \mathrm{s}$ just below it, increasing to $7.6-7.7 \mathrm{~km} / \mathrm{s}$ a few kilometers lower, does a reasonable job in fitting the mantle reflection and refraction travel time data but is not especially well constrained. We interpret the reflector to be the Moho under Iceland, and the prominent reflections indicate that it is fairly sharp. The key observations for this interpretation are the sharpness of the reflector and the $7.7 \mathrm{~km} / \mathrm{s}$ apparent upper mantle velocity just below it. It is, however, necessary to know in what physical state a 7.7 $\mathrm{km} / \mathrm{s}$ fast upper mantle is in, before affirming that the reflections are from the crust-mantle boundary. We explore some possibilities below.

The Moho, as determined by forward modeling of travel times, dips slightly to the west (Figure 6). Wide-angle reflections observed from it are probably from the east and west of the WVZ, with only a few reflection points immediately beneath the WVZ. Consequently, we cannot definitively address whether the Moho is continuous across the WVZ. Several one-dimensional profiles of the final model are shown in Figure 7.

A wide-angle reflection observed on the RRISP profile is interpreted by Gebrande et al. [1980] to be from a localized high-velocity lens at $30 \mathrm{~km}$ depth [see Gebrande et al., 1980, Figure 1, shot D]. We see no strong argument for this reflector being associated with a thin layer and instead interpret it to be a reflection from $\sim 30 \mathrm{~km}$ deep Moho. Another RRISP profile [Gebrande et al., 1980, Figure 2] also contains evidence for a sharp Moho, since the apparent velocity increases sharply from approximately $7.0 \mathrm{~km} / \mathrm{s}$ to $7.67 \mathrm{~km} / \mathrm{s}$ at a range of $140 \mathrm{~km}$. No Moho reflection is observed on this RRISP record section, probably due to the low-frequency content of the data and spatial aliasing. Hence a relatively sharp Moho is probably a common feature in Iceland at least outside the volcanic zones.

\section{Mantle}

5. Upper mantle velocities reach 7.6-7.7 km/s a few kilometers beneath the Moho in Iceland. Implications are that previous temperature estimates have been overestimated at the top of the upper mantle in Iceland. The upper mantle velocities of $7.4 \mathrm{~km} / \mathrm{s}$ reported by RRISP may only be

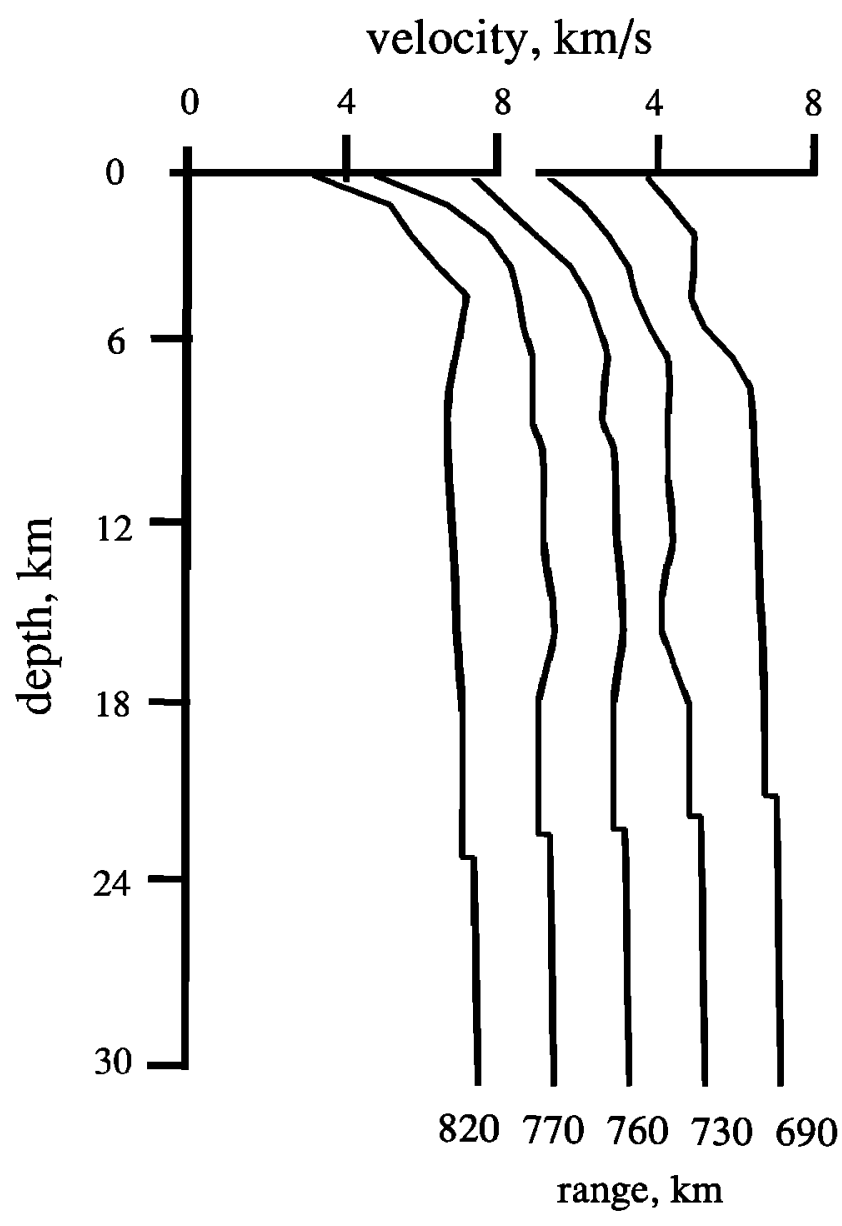

Fig. 7. Five one-dimensional profiles of compressional wave velocity through the final model. Profiles are displaced $2 \mathrm{~km} / \mathrm{s}$ from each other. Top scales are for first and last profiles.

representative of the NVZ itself. Tomographic inversion of teleseismic data have been interpreted by Tryggvason et al. [1983] to indicate the mantle velocity increases by $4 \%$ away from the NVZ to the older areas of eastern Iceland, which corresponds to an increase from 7.4 to $7.7 \mathrm{~km} / \mathrm{s}$. Some RRISP record sections that have rays that bottom at the periphery of the NVZ have apparent velocities of 7.67 and $7.7 \mathrm{~km} / \mathrm{s}$ [Gebrande et al., 1980, Figure 2, RRISP Working Group, 1980, Figure 4]. These measurements are in close agreement with our measurements of apparent velocity of $7.74 \mathrm{~km} / \mathrm{s}$ for shot JL (Figure 3).

Some authors [Tryggvason, 1964; Long and Mitchell, 1970] have proposed that very low upper mantle velocities exist below Iceland $(7.4 \mathrm{~km} / \mathrm{s}$ down to at least $160 \mathrm{~km}$ depth) on the basis of teleseismic travel time anomalies. However, we find that more recent anomaly data and velocity models [Dziewonski and Anderson, 1983] support somewhat higher velocities, similar to our 7.6-7.7 km/s sub-Moho value. $D z i e-$ wonski and Anderson [1983] find that the teleseismic $P$ wave travel time delay of Iceland is between 1.6 and $1.9 \mathrm{~s}$. This anomaly can be interpreted as a low-velocity zone in the upper $240 \mathrm{~km}$ of the mantle of Dziewonski and Anderson's [1981] Preliminary Reference Earth Model (PREM) from $8.0-8.1 \mathrm{~km} / \mathrm{s}$ to about $7.7 \mathrm{~km} / \mathrm{s}$ but do not require a velocity inversion within the uppermost mantle beneath Iceland.

In a dry state the mantle rock, peridotite, has a compressional velocity of $7.4 \mathrm{~km} / \mathrm{s}$ at $5 \mathrm{kbar}$ pressure $(\sim 20$ 
$\mathrm{km}$ depth) and at the solidus temperature $1180^{\circ} \mathrm{C}$ [Murase and Kushiro, 1979; Sato et al., 1989a; Takahaskhi, 1986] (and compiled by Sato et al., 1989b].) We therefore believe that the $7.7 \mathrm{~km} / \mathrm{s}$ refractor under south Iceland is below the solidus temperature of peridotite, if we assume that the upper mantle rocks in Iceland are peridotite. Accordingly, steady state accumulations of partial melt do not seem to occur at the top of the upper mantle, and hence melt generation must be at greater depths. Unfortunately the lab data of Murase and Kushiro [1979] and Sato et al. [1989a] do not extend to low enough temperatures to determine directly the temperature of $7.7 \mathrm{~km} / \mathrm{s}$ peridotite. An approximate estimate of this temperature can be made by assuming that the linear velocity-temperature gradient of olivine $\left(5.2 \times 10^{-4} \mathrm{~km} / \mathrm{s}^{\circ} \mathrm{C}\right.$ [Anderson et al., 1992]) applies to peridotite. This extrapolation gives a temperature of $600^{\circ} \mathrm{C}$. If, however, we extrapolate the very few velocity values of peridotite that are below the solidus determined by Murase and Kushiro [1979] and Sato et al. [1989a] to lower temperatures, we obtain a temperature estimate of $900^{\circ} \mathrm{C}$ for $7.7 \mathrm{~km} / \mathrm{s}$ peridotite. The solidus of gabbro at $5 \mathrm{kbar}$ confining pressure is $1090^{\circ} \mathrm{C}$ [Thompson, 1975]. Hence gabbro is below its solidus in the inferred range of Moho temperatures. The only remaining question is if crustal rocks at 20 $\mathrm{km}$ depth can have the observed velocities of 7.0-7.2 km/s at the relatively high temperature under Iceland.

Lower oceanic crustal velocities are reported to lie in the range $6.5-7.2 \mathrm{~km} / \mathrm{s}$ (e.g., Minshull et al., [1991]), but are usually found in colder crust than in Iceland. The fastest gabbro sampled from the lower crustal portion of an ophiolite site in Papua New Guinea has velocity of $7.69 \mathrm{~km} / \mathrm{s}$ at $5 \mathrm{kbar}$ and room temperature [Kroenke et al., 1976]. A linear extrapolation of this velocity to $600-900^{\circ} \mathrm{C}$ leads to a velocity drop to $7.1-6.7 \mathrm{~km} / \mathrm{s}$. Olivine gabbro sampled from an ophiolite site in Oman has a velocity $0.12 \mathrm{~km} / \mathrm{s}$ faster than the fastest gabbro from New Guinea, when measured at the same temperature and pressure [Christensen and Smewing, 1981]. It is therefore plausible that olivine rich gabbro could account for seismic velocities up to 7.2 $\mathrm{km} / \mathrm{s}$ in the relatively hot lower crust of Iceland. Some geochemists expect that the lower crust of Iceland should have a larger proportion of olivine than "normal" oceanic lower crust, due to the influence of the hotspot (C. Langmuir, personal communication, 1992). Elevated temperatures under Iceland cause melting to occur at higher temperature and greater pressure (depth) in the mantle than under normal ridges, producing olivine-rich melt. Part of this melt will crystallize into olivine gabbro in the lower crust. Olivine enrichment has the effect of raising seismic velocities.

Our new interpretation of crustal thickness in south Iceland, between 20 and $24 \mathrm{~km}$, agrees well with expected thickness of crust over hotspots as determined by geochemical arguments [McKenzie, 1984; Klein and Langmuir, 1987; Sleep, 1990].

The new interpretation for the lower crust presented here is not consistent with previous estimates of temperature between 1000 and $1100^{\circ} \mathrm{C}$ in the depth range 10-20 km [Pálmason and Semundsson, 1974]. In this depth and temperature range a large proportion of crustal material would be molten and seismically slow. Hence previous authors concluded that velocities of $7.0-7.2 \mathrm{~km} / \mathrm{s}$ should be attributed to mantle rocks. The older estimates of temperature at 10$20 \mathrm{~km}$ depth were obtained by linear extrapolation of the measured geotherm in the top 0-2 $\mathrm{km}$ part of the crust. However, a simple, one-dimensional thermal structure calculation for a ridge [e.g. Sparks and Parmentier, 1991] shows that geothermal gradients decrease with depth. We therefore believe that previous temperatures estimates have been overestimated.

\section{Crustal Anomalies}

6. A broad high-velocity zone domes in the lower crust beneath the WVZ median valley (754-767 km) and extends 30 $\mathrm{km}$ farther to the west along the profile. No magma chamber is seen within the WVZ at the transect. The velocity is elevated by about $0.5 \mathrm{~km} / \mathrm{s}$ (i.e., from 6.5 to $7.0 \mathrm{~km} / \mathrm{s}$ ) at a depth of $5 \mathrm{~km}$. The deepest rays, which bottom at a depth of about $12 \mathrm{~km}$ in the WVZ, have apparent velocities of 7.13 $\mathrm{km} / \mathrm{s}$. The shape of the dome at the bottom of the inversion model $(15 \mathrm{~km})$ is essentially unconstrained, as are the high velocities $(>7.3 \mathrm{~km} / \mathrm{s})$. The dome of high velocities under the ridge axis may represent a region of the lower crust that has been enriched in olivine by plutonism. This seismically fast material may be advected to greater depths in the crust as it ages and spreads [Pálmason, 1980].

The high midcrustal velocities indicate that a large magma chamber is not present beneath the WVZ. Careful inspection of the travel time of the AK, BF, and JL profiles (Figure 5), which have rays that pass subvertically through the midcrust at the WVZ, reveals no pronounced delays that might be associated with a magma chamber. (In fact, those portions of the travel time curves are generally fast.) We feel that the maximum plausible amplitude of a "hidden" travel time delay is about $0.1 \mathrm{~s}$, which gives a maximum magma chamber thickness of $0.6 \mathrm{~km}$ (for magma velocities of $3 \mathrm{~km} / \mathrm{s}$ ). Vera et al. [1990] modeled the East Pacific Rise (EPR) magma chamber as being $2 \mathrm{~km}$ wide and $0.7 \mathrm{~km}$ thick. Our data cannot rule out a small magma chamber of this type. On the other hand, Vera et al.'s [1990] crustal velocity model (their Figure 22) shows a broad depression of velocities throughout all of layer 3 out to a lateral distance of $5 \mathrm{~km}$. Our inversion rules out the presence of this kind of broad low-velocity zone beneath the WVZ.

7. Upper crustal velocities are high beneath extinct central volcanos west of the WVZ. The upper crustal velocities are elevated by $\sim 0.5 \mathrm{~km} / \mathrm{s}$ in the vicinity of the Stardalur extinct central volcano (775-785 km, Figure 1 and Plate 3 ). The surface geology of this region is dominated by massive basaltic plutons, which are seismically faster than the surrounding layered flood basalts. The depth to the lower crust is shallowest in this area, $\sim 2.5 \mathrm{~km}$. Flóvenz [1980] had previously noted that of all places measured in Iceland the shallowest depth to the lower crust $(2.0 \mathrm{~km})$ occurs under the Stardalur Caldera. A smaller, fast travel time anomaly was observed along the Skardsheidi extinct central volcano (800-815 km, Figure 1 and Plate 3 ).

8. The axis of the spreading center in the WVZ (754-767 km) coincides with a very sharp change in the thickness of the upper crust from $0.8 \mathrm{~km}$ west of the WVZ to $2.0 \mathrm{~km}$ in the WVZ, but a uniform midcrust (Plate 3). The thin upper crust west of the WVZ is not confined to our profile but extends northward by at least $20 \mathrm{~km}$ where Zverev et al. [1980] have measured a 40-km-long profile (their profile I). Rays in their profile that bottom at the layer $2 \mathrm{~A} / 2 \mathrm{~B}$ boundary (i.e., apparent velocity $\sim 5.0 \mathrm{~km} / \mathrm{s}$ ) have travel times only about $0.1 \mathrm{~s}$ slower than our values west of the WVZ, 
indicating very similar upper crustal thicknesses. (However, rays bottoming at the top of Layer 3 are delayed by approximately $0.45 \mathrm{~s}$ in their data set compared to ours, indicating that the midcrust is about $1.0 \mathrm{~km}$ thicker along their profile than ours.)

9. A 2.5-km-deep upper crustal velocity low occurs under the eastern edge of the WVZ and the hyaloclastite ridge, Búrfell extending to the eastern edge of the medium valley of the WVZ (748-754 km) (Plate 3). The abrupt termination of this feature on the east side $(748 \mathrm{~km})$ is probably related to an intruding upper crustal velocity high under the off-axis Grímsnes volcanic center (Figure 1).

10. A narrow upper and midcrustal velocity high at (738$747 \mathrm{~km}$ ) is associated with the off-axis Grimsnes volcanic center which is postglacial in age [J6hannesson and SRmundsson, 1989] (740-746 km, Plate 3). We note that the lower crust beneath the volcanically active WVZ, as well as the midcrust under the much smaller Grímsnes volcanic center, are characterized by faster than average seismic velocities. Fast velocities may be caused by high geothermal alteration (which leads to a reduction in porosity) and by the unusually numerous lower crustal intrusions below the volcanic centers.

11. A broad crustal low-velocity zone approximately coincides with the transform of the South Iceland Seismic Zone $(721-735 \mathrm{~km})$. The low-velocity zone is approximately 15 km wide and extends from the upper crust into the lower crust to a depth of $10 \mathrm{~km}$ between 727 and $740 \mathrm{~km}$. Velocity reduction is approximately $0.3 \mathrm{~km} / \mathrm{s}$ or $5 \%$.

12. The narrow, slow upper crustal velocity zone near the southeastern end of profile $(695-708 \mathrm{~km})$ has no clear correspondence to surface geology. The surface in this region is covered with glacial outwash [Jóhannesson and Samundsson, 1989].

\section{CONCLUSIONS}

The depth to the lower crust ("layer 3") is asymmetric across the WVZ. On average the depth to the lower crust is $3.0 \mathrm{~km}$ northwest of the WVZ, $4.3 \mathrm{~km}$ in the WVZ, and 6.0 $\mathrm{km}$ southeast of the WVZ. The asymmetry may in part be explained by greater amount of crustal erosion to the northwest of the WVZ and due to secondary crustal accretion in the South Iceland Lowlands associated with the ride jumping from the WVZ to the EVZ. A broad high-velocity zone domes in the lower crust beneath the WVZ median valley and extends $30 \mathrm{~km}$ farther to the northwest along the profile. The dome may represent a region of the lower crust that has been enriched in olivine by plutonism. No magma chamber is seen within the WVZ at the transect. This experiment sampled only a narrow cross section of the WVZ, and therefore we cannot generalize about the existence of magma chambers in other parts of the WVZ. Indeed, the Hengill central volcano, which has had postglacial eruptions, is $10 \mathrm{~km}$ southwest of the profile.

The crust in south Iceland is $\mathbf{2 0 - 2 4} \mathrm{km}$ thick with a sharp reflector at the bottom which we interpret as the Moho. This is significantly thicker crust than has been postulated by most previous investigators. A relatively sharp Moho is probably a common feature in Iceland, at least outside the volcanic zones. Upper mantle velocities reach $7.6-7.7 \mathrm{~km} / \mathrm{s}$ a few kilometers beneath the Moho in south Iceland. Implications are that the lower crust and the top of the upper mantle are colder than previously postulated.
Acknowledgments. This research was supported by the U.S. National Science Foundation, the Iceland National Science Foundation, the National Energy Authority of Iceland, the Incorporated Research Institutions for Seismology, IcelandAir, and the Lamont-Doherty Geological Observatory of Columbia University. We thank the many landowners in Iceland that graciously allowed access to their land. We thank the Science Institute of the University of Iceland, Roger Bilham of the University of Colorado, Walter Mooney of the U.S. Geological Survey, Klaus Jacob of the National Center for Earthquake Engineering Research and Gudmundur Sigvaldason at the Nordic Volcanological Institute for loans of equipment. We thank Benedikt Steingrimsson, Bryndis Brandsdóttir, Gunnlaugur Gudmundsson, Einar Haraldsson, Einar Kjartansson, Halldór Jónsson, Hilmar Sigvaldason, Hrappur Magnússon, Jósep Hólmjárn, Larry Shengold, Páll Helgason, and Ragna Karlsdóttir for technical assistance. We are grateful for the good work all these people performed but would like to thank shotmaster Jósep Hólmjárn in particular. We thank Gunnar Thorbergsson for use of his geodetic programs. This paper benefited from discussion with Won-Young Kim, John Mutter, Páll Einarsson, Ge Hu and Marc Spiegelman, and from comments from anonymous reviewers. Lamont-Doherty Contribution 5040.

\section{References}

Anderson, O. L., D. Isaak, and H. Oda, High-temperature elastic constant data on minerals relevant to geophysics, Rev. Geophys, 30, 57-90, 1992.

Bath, M., Crustal structure of Iceland, J. Geophys. Res. 65, 1793-1807, 1960.

Bjarnason, I. Th., P. Cowie, M. H. Anders, L. Seeber, and C. H. Scholz, The 1912 Iceland earthquake rupture: Growth and development of a nascent transform, Bull. Seismol. Soc. Am., in press, 1993.

Beblo, M., and A. Björnsson, A model of electrical resistivity beneath NE-Iceland, correlation with temperature, J. Geophys., $47,184-190,1980$.

Bott, M. H. and K. Gunnarsson, Crustal structure of the IcelandFaeroe Ridge, J. Geophys., 47, 221-227, 1980.

Caress, D. W., M. S. Burnett, and J. A. Orcutt, Tomographic image of the axial low-velocity zone at $12^{\circ} 50^{\prime} \mathrm{N}$ on the East Pacific Rise, J. Geophys. Res., 97, 9243-9263, 1992.

Cerveny, V., and I. Psencik, 2-D seismic ray package, Seis81, Charles Univ., Prague, 1981.

Christensen, N. I., and J. D. Smewing, Geology and seismic structure of the northern section of the Oman ophiolite, J. Geophys. Res., 86, 2545-2555, 1981.

Dziewonski, A. M., and D. L. Anderson, Preliminary Reference Earth Model, Phys. Earth Planet. Inter., 28, 297-356, 1981.

Dziewonski, A. M. and D. L. Anderson, Travel times and station corrections for $\boldsymbol{P}$ waves at teleseismic distances, $J$. Geophys. Res., 88, 3295-3314, 1983.

Einarsson, P., and J. Eiriksson, Earthquake fractures in the districts Land and Rangárvellir in the South Iceland Seismic Zone, Jökull, 32, 113-120, 1982.

Einarsson, P., and K. Sæmundsson Earthquake epicenters 1982 1985 and volcanic systems in Iceland (map), in "f hlutarins edli", Festschrift for Thorbjörn Sigurgeirsson, edited by Th. Sigfússon, Menningarsjódur, Reykjavík, 1987.

ETOPO5: Digital relief of the surface of the earth - Bathymetry/Topography data, Rep. 88-M66-2, Natl. Oceanic and Atmos. Admin, Boulder, Colo., 1988.

Eysteinsson, H., and J. F. Hermance, Magnetotelluric measurements across the eastern neovolcanic zone in south Iceland, $J$. Geophys. Res., 90, 10093-10103, 1985.

Flóvenz, Ó. G., Seismic structure of the Icelandic crust above layer three and the relation between body wave velocity and the alteration of the basaltic crust, J. Geophys., 47, 211-220, 1980.

Flóvenz, Ó. G., and K. Gunnarsson, Seismic crustal structure in Iceland and surrounding area, Tecton ophysics 189, 1-17, 1991.

Flóvenz, $O$. G., and K. Sæemundsson, Heat flow and geothermal processes in Iceland, Tectonophysics, in press, 1993.

Gebrande, H., H. Miller, and P. Einarsson, Seismic structure of Iceland along RRISP-profile I, J. Geophys., 47, 239-249, 1980. 
Goldflam, P., W. Weigel, and B. D. Loncarevic, Seismic structure along RRISP-Profile I on the southeast flank of the Reykjanes Ridge, J. Geophys. 47, 250-260, 1980.

Hackman, M. C., G. C. P. King, and R. Bilham, The mechanics of the South Iceland Seismic Zone, J. Geophys. Res., 95, 17,339$17,351,1990$.

J6hannesson H., and K. Særmundsson, Geological map of Iceland, in Bedrock geology, 1st ed., Icelandic Museum of Natural History and Iceland Geodetic Survey, Reykjavík, 1989.

Klein, E., and C. H. Langmuir, Global correlations of ocean ridge basalt chemistry with axial depth and crustal thickness, $J$. Geophys. Res., 92, 8089-8115, 1987.

Kroenke, L. W., M. H. Manghnani, C. S. Rai, P. Fryer, and R. Ramananan-toandro, Elastic properties of selected ophiolitic rocks from Papua New Guinea: Nature and composition of the oceanic lower crust and upper mantle, in Geophysics of the Pacific Ocean Basin and Its Margin, Geophys. Monogr. Ser., vol. 19, edited by G. H. Sutton, M. H. Manghnani, R. Moberly, pp. 407-421, AGU, Washington, D.C., 1976.

Long, R. E., and M. G. Mitchell, Teleseismic P-wave delay time in Iceland, Geophys. J. R. Astron. Soc., 20, 41-48, 1970.

McKenzie, D., The generation and compaction of partially molten rock, J. Petrol., 25, 713-765, 1984.

Minshull, T. A., R. S. White, J. C. Mutter, P. Buhl, R. S. Detrick, C. A. Williams, and E. Morris, Crustal structure at the Blake Spur fracture zone from expanding spread profiles, J. Geophys. Res., 96, 9955-9984, 1991.

Morgan, W. J., Rodriguez, Darwin, Amsterdam, .., A second type of hotspot island, J. Geophys. Res. 83, 5355-5360, 1978.

Murase, T., and I. Kushiro, Compressional wave velocity in partially molten peridotite at high pressures, Year Book Carnegie Inst. Washington, 79, 559-562, 1979.

Mutter, C. Z., and J. C. Mutter, Variations in thickness of layer 3 dominate oceanic crustal structure, Earth Planet. Sci. Lett. in press, 1993.

Oskarsson, N., S. Steinthórsson, and G. E. Sigvaldason, Iceland geochemical anomaly: Origin, volcanotectonics, chemical fractionation and isotope evolution of the crust, J. Geophys. Res. $90,10,011-10,025,1985$.

Pálmason, G., Crustal structure of Iceland from explosion seismology, Greinar Visindafélag $I_{s l}$., 40,187 pp, 1971.

Pálmason, G., A continuum model of crustal generation in Iceland: Kinematic aspects, J. Geophys., 47, 7-18, 1980.

Pálmason, G., and K. Sæmundsson, Iceland in relation the MidAtlantic Ridge, Annu. Rev. Earth Planet. Sci., 2, 25-50, 1974.

RRISP Working Group, Reykjanes Ridge Iceland Seismic Experiment (RRISP 77), J. Geophys., 47, 228-238, 1980.

Sæmundsson, K., Evolution of the axial rifting zone in northern Iceland and the Tjörnes fracture zone, Geol. Soc. Am. Bull., 85, 459-504, 1974.

Sæmundsson, K., Outline of the geology of Iceland, Jökull, 29, 7-28, 1979.

Sato, H., I. S. Sacks, and T. Murase, The use of laboratory velocity data for estimating temperature and partial melt fraction in the low-velocity zone: Comparison with heat flow and electrical conductivity studies, J. Geophys. Res., 94, 5689-5704, $1989 a$.

Sato, H., I. S. Sacks, T. Murase, G. Muncill, and H. Fukuyama, $Q p$-Melting temperature relation in peridotite at high pressure and temperature: Attenuation mechanism and implications for the mechanical properties of the upper mantle, $J$. Geophys. Res., 94, 10,647-10,661, 19896.

Sleep, N., Hotspots and mantle plumes: Some phenomenology, $J$. Geophys. Res., 95, 6715-6736, 1990.

Sparks, D. W., and E. M. Parmentier, Melt extraction from the mantle beneath spreading centers, Earth Planet. Sci. Lett., $105,368-377,1991$.

Takahashi, E., Melting of a dry peridotite KLB-1 up to $14 \mathrm{GPa}$ Implications on the origin of peridotitic upper mantle, J. Geophys. Res., 91, 9367-9382, 1986.

Thompson, R. N., Primary basalts and magma genesis, Contrib. Mineral., Petrol., 52, 213-232, 1975.

Tryggvason, E., Arrival times of $P$ waves and upper mantle structure, Bull. Seismol. Soc. Am., 54, 727-736, 1964.

Tryggvason, E., and M. Bath, Upper crustal structure of Iceland, J. Geophys. Res., 66, 1913-1925, 1961.

Tryggvason, K., E. S. Husebye, and R. Stefánsson, Seismic image of the hypothesized Icelandic hot spot, Tectonophysics, 100, 97-118, 1983.

Vera, E., J. C. Mutter, P. Buhl, J. A. Orcutt, A. J. Harding, M. E. Kappus, R. S. Detrick and T. M. Brocher, The structure of 0-to 0.2-m.y.- old oceanic crust at $9^{\circ} \mathrm{N}$ on the East Pacific Rise from expanded spread profiles, J. Geophys. Res., 95, 15,529$15,556,1990$.

Vink, G. E., A hotspot model for Iceland and the Vöring Plateau, J. Geophys. Res., 89, 9949-9959, 1984.

Zverev, S. M., I. P. Kosminskaya, G. A. Krasilstchikova, and G. G. Mikhota, The crustal structure of Iceland and the IcelandFaeroe-Shetland region, Byull. Mosk. Ova. Ispyt. Prir., Otd. Geol. 50, 72 pp., 1975.

Zverev, S. M., I. V. Litvinenko, G. Palmason, G. A. Yaroshevskaya, and N. N. Osokin, A seismic crustal study of the axial rift zone in southwest Iceland, J. Geophys., 47, 202-210, 1980.

I. Th. Bjarnason, Carnegie Institution of Washington, Department of Terrestrial Magnetism, 5241 Broad Branch Road, N.W., Washington, D.C. 20015.

D. Caress and W. Menke, Lamont-Doherty Earth Observatory, Palisades, NY 10964.

6. G. Flóvenz, Orkustofnun, Grensásvegi 9, 108 Reykjavik, Iceland.
(Received June 4, 1992; revised September 28, 1992; accepted October 6, 1992.) 